\title{
Scaling up and zooming in: global history and high-definition archaeology perspectives on the longue durée of urban-environmental relations in Gerasa (Jerash, Jordan)
}

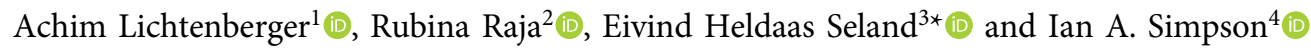 \\ ${ }^{1}$ Institut für Klassische Archäologie und Christliche Archäologie/Archäologisches Museum, Westfälische Wilhelms-Universität \\ Münster, Münster, Germany, ${ }^{2}$ Aarhus University and Centre for Urban Network Evolutions, Aarhus University, Aarhus, \\ Denmark, ${ }^{3}$ Department of Archaeology, History, Cultural Studies and Religion, University of Bergen, Bergen, Norway and \\ ${ }^{4}$ Biological and Environmental Sciences, University of Stirling, Stirling, Scotland, UK \\ ${ }^{\star}$ Corresponding author. E-mail: eivind.seland@uib.no
}

\begin{abstract}
Combining global perspectives with localized case studies and integrating scientific and material evidence of environmental change in historical narratives are amongst the main challenges for the field of global history in addressing the dawn of the Anthropocene. In this article, we trace the relationship of the city of Gerasa (Jerash, Jordan) with its riverine hinterland, from the first millennium BCE until the nineteenth century CE. We argue that the study of long-term historical trajectories of microregions not only depends on context from regional and global history timelines, but also has the potential to provide insights relevant to those scales in return. Zooming in and scaling up must go hand in hand in order for global history perspectives to be properly informed, and archaeology and natural sciences have crucial insights to offer - although importantly only when evidence comes from well-contextualized frameworks.
\end{abstract}

Keywords: Near East; urban environments; riverine landscapes; urban and global history; longue durée; high-definition archaeology

\section{Introduction}

At the outset of the Anthropocene, the disciplines of archaeology and history are increasingly challenged to address past relationships between human and environmental agencies in ways that are relevant to present-day audiences. ${ }^{1}$ As pointed out by John R. McNeill in his presidential address to the American Historical Association 2020 annual meeting, our knowledge of the past increasingly stems from natural sciences, and this trend is stronger the further back into the past our investigations bring us. ${ }^{2}$ This is all the more true for parts of the world where text production was limited or has not been handed down to us. Global history as a discipline, in particular, is

Co-authorship: There is no lead author on the article. All authors performed research, analysed data and wrote the article.

${ }^{1}$ Dipesh Chakrabarty, "The Climate of History: Four Theses," Critical Inquiry 35, no. 2 (2009): 197-222; Dipesh Chakrabarty, “Anthropocene time," History and Theory 57, no. 1 (2018): 5-32; Jo Guldi and David Armitage, The History Manifesto (Cambridge: Cambridge University Press, 2014).

${ }^{2} J o h n$ R. McNeill, "Peak Document and the Future of Historical Research," (Presidential Address to the American Historical Association 2020 annual meeting, Washington DC, January 4, 2020), https://aha.confex.com/aha/2020/ webprogram/Session20540.html/https://youtu.be/XR8VEQaPNdo

( The Author(s), 2021. Published by Cambridge University Press. This is an Open Access article, distributed under the terms of the Creative Commons Attribution licence (http://creativecommons.org/licenses/by/4.0/), which permits unrestricted re-use, distribution, and reproduction in any medium, provided the original work is properly cited. 
committed to address issues on a global scale or with global relevance, both through empirical studies and theoretical approaches. Long-term human-environment balances should be at the top of the list, but require cross-disciplinary work that few historians possess the necessary skills, interest or funding for. Leaving the field to the natural sciences exclusively is not a satisfactory option, however. Archaeology and history offer the study of paleo-environmental data as products of culturally situated practices, well suited to address the nature of human-environment entanglements in the past. ${ }^{3}$ While debates on whether and at what point in history the Anthropocene becomes a useful analytical term continue, ${ }^{4}$ pre-modern history may help us appreciate how not only our present-day institutions, but also our relationship with the environment relies on cultural practices and historical contingencies. ${ }^{5}$

How may archaeological and natural science data be integrated more holistically into the development of historical narratives? Below, we argue that one way of facing these challenges and tackling meaningful integration of data pulled from other disciplines is by zooming in on case studies that can be investigated through high-definition perspectives and from multiple angles, and then scaling up, by juxtaposing the results with global-scale environmental and historical timelines, which are in turn refined by the detailed information offered by the case studies. ${ }^{6}$ A case study approach is crucial since it provides data that contributes to a nuanced regional picture of humanenvironment entanglements in the past. Our chosen case is the city of Jerash in present-day Jordan and its relationship to the watercourse that literally runs through the city over a period of more than 2500 years (Figure 1). Using an urban biography as a point of departure enables us to identify the benign trends and negative stresses that fostered resilience or caused vulnerability, and the positive events as well as shocks that in retrospect can be identified as breaking points in the life story of Jerash. ${ }^{7}$ Combining the limited traditional historical record available with archaeology and paleo-environmental data, we aim to demonstrate how human and environmental agencies both shaped the biography of the city, and how a case study such as that of Jerash may in turn contribute back to regional and global-scale historical narratives. Our narrative emphasizes the material, economic and ecological aspects of development. This does not come at the expense of other aspects of the human past, but reflects the nature of our sources, our ambition to answer the calls that historians need to engage with archaeological and scientific data, and our belief that the timescale of the longue durée is the optimal framework for doing this. ${ }^{8}$ As we aim to demonstrate below, ideological, cultural and political change is frequently manifested in the material record, in most cases arguably as a cause, in other cases also as an effect.

\footnotetext{
${ }^{3}$ Michael Lewis, “And All Was Light?-Science and Environmental History”, in The Oxford Handbook of Environmental History, ed. Andrew C. Isenberg (Oxford: Oxford University Press, 2014): 207-26.

${ }^{4}$ Paul J. Crutzen, The "Anthropocene", in Earth System Science in the Anthropocene, eds. Eckart Ehlers and Thomas Krafft (Berlin: Springer, 2006): 13-18; Arlene M. Rosen, Jinok Lee, Min Li, Joshua Wright, Henry T. Wright, and Hui Fang, “The Anthropocene and the Landscape of Confucius: A Historical Ecology of Landscape Changes in Northern and Eastern China during the Middle to Late-Holocene," The Holocene 25, no. 10 (2015): 1640-50.

${ }^{5}$ Joseph G. Manning, The Open Sea: The Economic Life of the Ancient Mediterranean World from the Iron Age to the Rise of Rome (Princeton: Princeton University Press, 2018); Paul J. Lane, "Archaeology in the age of the Anthropocene: A critical assessment of its scope and societal contributions," Journal of Field Archaeology 40, no. 5 (2015): 485-98.

${ }^{6}$ Rubina Raja and Søren M. Sindbæk (eds.), Urban Network Evolutions. Towards a High Definition Archaeology (Aarhus: Aarhus University Press, 2018) for a volume which through 40 case studies pioneered such an approach.

${ }^{7}$ On urban biographies, archaeology and high-definition studies, see the newly published journal issue also for a contribution on Jerash: Rubina Raja and Søren M. Sindbæk, "Biographies of Place - An Introduction," Journal of Urban Archaeology 2 (2020): 11-4. DOI: 10.1484/J.JUA.5.121525. Rubina Raja and Søren M. Sindbæk, "Urban networks and high-definition narratives. Rethinking the archaeology of urbanism," Journal of Urban Archaeology 2 (2020): 173-86. DOI: 10.1484/ J.JUA.5.121535. Achim Lichtenberger and Rubina Raja, "Antioch on the Chrysorrhoas - Formerly Called Gerasa. Perspectives on Biographies of a Place,” Journal of Urban Archaeology 2 (2020): 151-72.

${ }^{8}$ Fernand Braudel, "History and the Social Sciences: The Longue Durée," Review (Fernand Braudel Center) 32, no. 2 (2009): 171-203.
} 


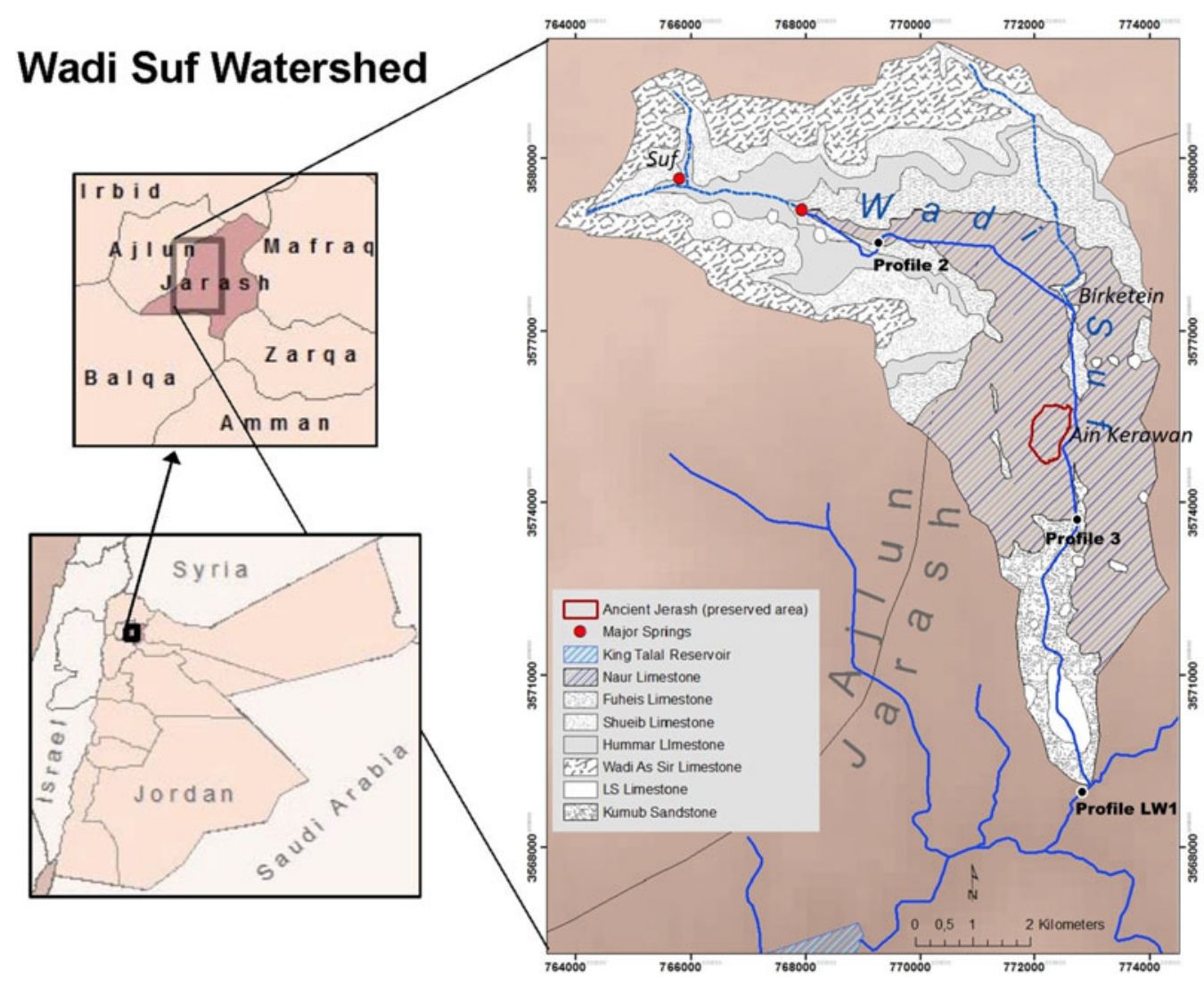

Figure 1. The Wadi Suf Watershed is the fertile riverine hinterland of Gerasa (modified from Nezar Hammouri and Ali El-Naqa, "GIS-based hydrogeological vulnerability mapping of groundwater resources in Jerash area-Jordan," Geofisica Internacional 47 (2008): 85-97; DEM from USGS, 2011).

\section{Scales of analysis in environmental history}

Scholars approach environmental history on different scales. Much work takes place either on a site or location level, or that of a landscape, mostly in the concrete, physical and perceived senses, but sometimes generalized to regional on the scales of deserts, forests, rivers, mountains, oceans, environs, etc., or on national, continental or global scales. Taking a localized case study as our point of departure and explicitly setting out to address different scales of analysis enables us to consider agencies and dynamics and the relationship between them from a new perspective.

Scientific data (submolecular and molecular), archaeological evidence (object, structure, settlement, hinterland) and documentary sources (individual, group, place) mostly represent geographically pinpointed evidence of past processes. In historical narratives, they may be said to offer high-definition information. ${ }^{9}$ The strength of such data is its potential, within margins depending on circumstances, to yield secure and testable knowledge. Major weaknesses include the fragmentary and possibly insecure nature of individual data points as well as datasets. Even the best paleoclimatic series have limited accuracy and might only be representative of the site that produced them. Archaeological data is shaped by the extent of the survival of the material and the archaeological process including excavation methods, interpretations and publication standards. Various kinds of documents are notoriously biased and unrepresentative, and rarely directly address the issue that the historian is interested in.

\footnotetext{
${ }^{9}$ See note 4.
} 
With Horden and Purcell's seminal The Corrupting Sea, the ecological microregion was suggested as the default unit of analysis for human-nature interaction, constituting a suitable bridge between the specialized (high-definition) interest of scientists and the social, economic and political questions raised in most historical studies. ${ }^{10}$ Micro-ecologies, as Horden and Purcell call them, are shaped by the natural environment, but defined through the interplay with human risk-management, creating villages, fields, pastureland, woodlands, etc. For most people in the pre-modern world, much of daily life and interaction took place within the framework of such crucial ecological systems, which, however, were also connected within and across wider regions and over longer distances through innumerable direct and indirect ties. ${ }^{11}$ In the case of Jerash, the drainage basin of Wadi Jerash, the river that runs through the city, represents a clear-cut unit of analysis, allowing the study of humannature interplay within a defined system (Figure 1). ${ }^{12}$ On a somewhat larger scale, the highlands of Ajlun, a dry-farming region between Lake Tiberias, the Jordan River, the Dead Sea and the Syrian Desert, also represent a distinct ecological microregion, ${ }^{13}$ while the historical landscape of northeastern modern Israel, northern Jordan and southern Syria known in Roman times as the Decapolis region, has an obvious historiographical relevance, but is much harder to delimit. ${ }^{14}$

The Decapolis is part of what has been defined as a historical mesoregion, which is an area crossing political and cultural borders, but connected by shared characteristics and frequent interaction. ${ }^{15}$ The wider mesoregion of the semi-arid Near East (Figure 2), stretching from Jordan to Northern Syria and Iraq, shares historical traits across time and space, including the related factors of vulnerability to climate change, geopolitical position in the transition zone between agricultural empires and the deserts, as well as shifting dynamics between nomads and settled populations. This level of analysis also allows for investigating relations with neighbouring mesoregions, including the Levantine Mediterranean coast, Eastern Anatolia as well as the Syrian and Arabian Deserts.

Just as the definition of and demarcation between ecological micro- and mesoregions are questions of scholarly inference rather than the physical environment, the border to the next category, the macroregions that have arguably been the most widespread units of analysis in ecologically oriented historical scholarship, is pragmatic. Our case study is situated within, but at the margin of the Mediterranean ecological zone, which has been the object of innumerable studies since Braudel's $L a$ Méditerranée et le monde méditerranéen à l'époque de Philippe II. ${ }^{16}$ It is also part of the less clearly defined macroregion of the Near East or the Levant. ${ }^{17}$ This scale of analysis is not only useful for discussing the ecological aspects of Jerash's history, but also in order to situate our case study in a

\footnotetext{
${ }^{10}$ Peregrine Horden and Nicholas Purcell, The Corrupting Sea: A Study of Mediterranean History (Oxford: Blackwell, 2000), 53-4, 77-80. Also see their recently published follow-up volume of collected writings since 2000: Peregrine Horden and Nicholas Purcell, The boundless sea. Writing Mediterranean History (London: Routledge, 2020).

${ }^{11}$ Horden and Purcell, Corrupting Sea, 122-52.

${ }^{12}$ Achim Lichtenberger and Rubina Raja, "The Chora of Gerasa/Jerash," in Judaea/Palaestina and Arabia: Cities and Hinterlands in Roman and Byzantine Times, eds. Achim Lichtenberger, Oren Tal and Zeev Weiss (Heidelberg: Propylaeum, 2019), 109-24.

${ }^{13}$ David Kennedy, “The Identity of Roman Gerasa: An Archaeological Approach,” Mediterranean Archaeology 11 (1998): 39-69; David Kennedy, Gerasa and the Decapolis. A 'virtual island' in northwest Jordan (London: Duckworth, 2007), 50-83.

${ }^{14}$ Hans Bietenhard, "Die syrische Dekapolis von Pompeius bis Trajan," in Aufstieg und Niedergang der römischen Welt II.8, eds. Hildegard Temporini and Wolfgang Haase (Berlin: De Gruyter, 1977), 220-61; Kennedy, Gerasa; Achim Lichtenberger, Kulte und Kultur der Dekapolis. Untersuchungen zu numismatischen, archäologischen und epigraphischen Zeugnissen (Wiesbaden: Harrassowitz, 2003), 6-20.

${ }^{15}$ Stefan Troebst, "Historical meso-region": a concept in cultural studies and historiography (Mainz: Inst. f. Europ. Geschichte, 2012).

${ }^{16}$ Fernand Braudel, La Méditerranée et le monde méditerranéen à l'époque de Philippe II (Paris: A. Colin, 1949); Later influential works include Horden and Purcell, Corrupting Sea, 9-49; David Abulafia, The Great Sea: A Human History of the Mediterranean (Oxford: Oxford University Press, 2011); Cyprian Broodbank, The Making of the Middle Sea: A History of the Mediterranean from the Beginning to the Emergence of the Classical World (London: Thames \& Hudson, 2015); Manning, The Open Sea.

${ }^{17}$ Terje Stordalen and Oystein Sakala LaBianca (eds.), Levantine Entanglements; Local Dynamics of Globalization in a Contested Region (Sheffield: Equinox, 2021).
} 


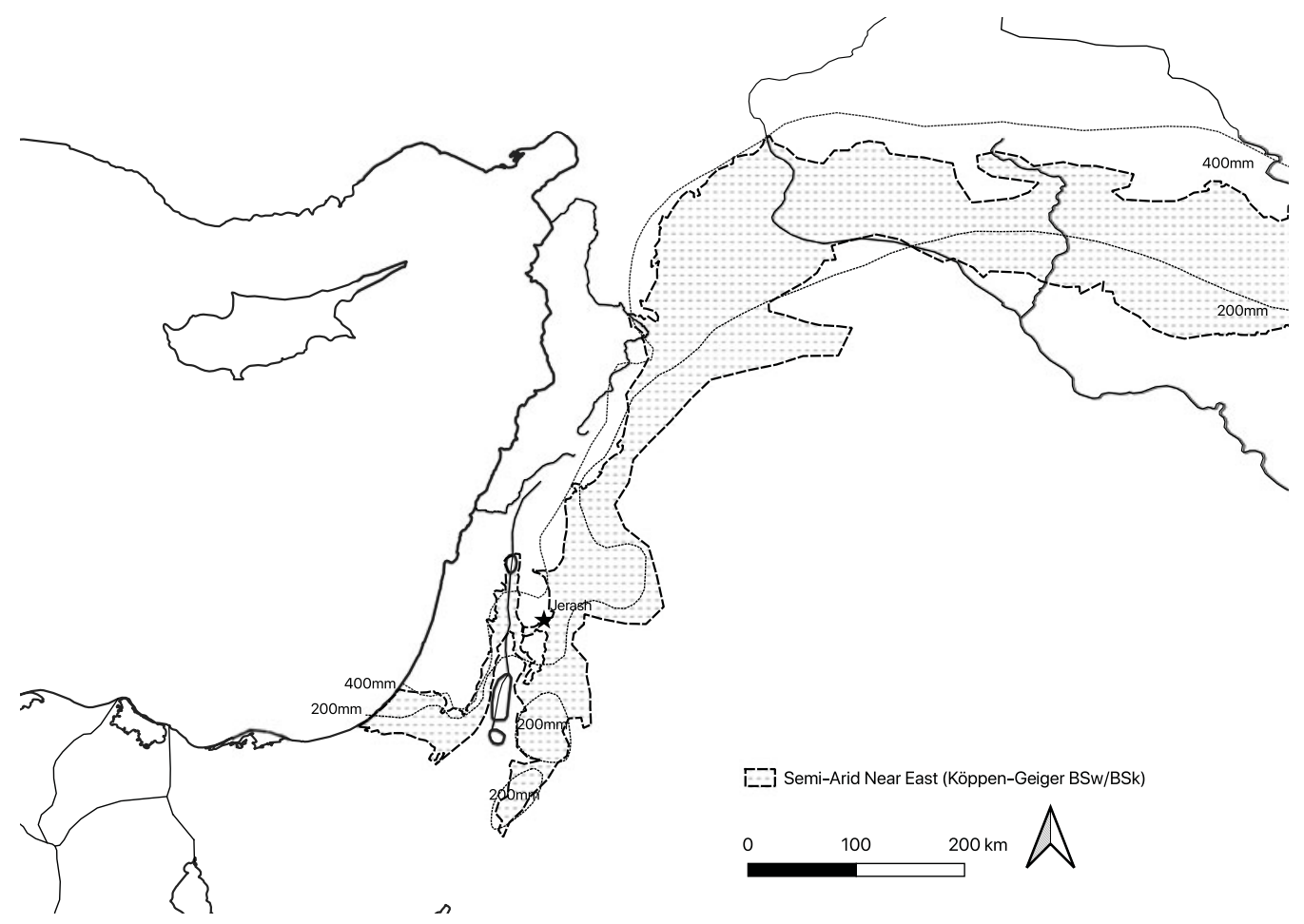

Figure 2. The Semi-Arid Near East, climate, rivers, lakes and isohyets. Data from Hylke E. Beck et al., "Present and future Köppen-Geiger climate classification maps at 1-km resolution," Scientific Data 5 (2018): 180214; Simone Riehl and Itzhaq Shai, "Supra-regional trade networks and the economic potential of Iron Age II sites in the Southern Levant," Journal of Archaeological Science: Reports 3 (2015): 525-33.

highly connected geopolitical narrative of empires, migrations, languages, religions, war, disease and long-distance trade - and so between concepts and developments.

Finally, the global scale of analysis contributes to developments that are likely to have resonated and thus be visible on the different regional levels, especially within climate history. Trends such as the Roman Climate Optimum, the Late Antique/Early Medieval Little Ice Age, ${ }^{18}$ the Medieval Climate Anomaly and the Early Modern Little Ice Age, ${ }^{19}$ and events such as the cold decade after $536 \mathrm{CE},{ }^{20}$ played out on a global scale, but had different effects and were met in diverse ways in different places. ${ }^{21}$

Our point of departure is that a holistic understanding of ecological history must address all these scales of analysis, from high definition to global, and that relationships and carriers of information between these scales are identified so they inform each other. In this way case studies also have the potential to constitute and contribute to macroregional and global history narratives, by providing details and depth sometimes missing at these scales, offering nuanced narratives with

\footnotetext{
${ }^{18}$ Paul Erdkamp, "War, Food, Climate Change, and the Decline of the Roman Empire," Journal of Late Antiquity 12, no. 2 (2019): 422-65; Kyle Harper, The Fate of Rome: Climate, Disease, and the End of an Empire (Princeton: Princeton University Press, 2017).

${ }^{19}$ Sarah Kate Raphael, Climate and Political Climate: Environmental Disasters in the Medieval Levant (Leuven: Brill, 2003); Elena Xoplaki et al., "Modelling Climate and Societal Resilience in the Eastern Mediterranean in the Last Millennium," Human Ecology 46, no. 3 (2018): 363-79.

${ }^{20}$ Timothy P. Newfield, “The Climate Downturn of 536-50," in The Palgrave Handbook of Climate History, eds. Sam White, Christian Pfister and Franz Mauelshagen (London: Palgrave Macmillan, 2018): 447-93.

${ }^{21}$ Johannes Preiser-Kapeller, Jenseits von Rom und Karl dem Großen. Aspekte der globalen Verflechtung in der langen Spätantike, 300-800 n. Chr. (Vienna: Mandelbaum, 2018); Fredrik Charpentier Ljungqvist, Klimatet och människan under 12000 år. (Stockholm: Dialogos, 2017).
} 
the opportunity to avoid linear cause and effect explanations. River systems with their complex interplay between humans and environment are ideal laboratories for zooming in locally and scaling up globally. ${ }^{22}$

\section{A river and its city - a city and its river}

The region of Jerash contains one of the largest and longest lasting Neolithic settlements in Jordan, ${ }^{23}$ demonstrating its attractiveness and potential for stable human habitation. ${ }^{24}$ This is in part due to the presence of the powerful Ain Kerawan spring, and also in part to the river system of Wadi Jerash, a tributary to the Zarqa River, which in turn drains into the Jordan River. Together, these features create the necessary conditions for permanent urban settlement and intensive agriculture. ${ }^{25}$ Fed by springs at Suf, 8 kilometres northwest of Jerash as well as a larger catchment area behind Suf, the river was called Chrysorrhoas, 'Gold-river', in antiquity, attesting to its perceived importance as well as prestige in a region where running surface water was relatively scarce. ${ }^{26}$ While the oldest yet documented urban settlement dates to the Hellenistic period, most probably the second century BCE, ${ }^{27}$ the survival and eventual success of the Semitic toponym of Gerasa seem to point towards the existence of an earlier, locally based settlement. ${ }^{28}$ At one point during Seleucid rule, the settlement was refounded and officially renamed as Antioch on the Chrysorrhoas. Adding the name of the river to the toponym, on the one hand, served to distinguish this city from the many other Seleucid foundations named Antioch, ${ }^{29}$ but it also underlined the importance of the river for the civic identity of the settlement. That the settlement nevertheless retained its local Semitic name throughout and beyond its urban existence points towards the resilience of local and possibly also non-urban populations despite a series of imperial initiatives. ${ }^{30}$

\footnotetext{
${ }^{22}$ Johannes C. Bernhardt, Markus Koller, Achim Lichtenberger (eds.), Mediterranean Rivers in a Global Perspective (Paderborn: Schöningh, 2019).

${ }^{23}$ Maysoon Al-Nahar, "The Neolithic Site of Tell Abu Suwwan in Jerash, Jordan," in The Archaeology and History of Jerash: 110 Years of Excavations, eds. Achim Lichtenberger and Rubina Raja (Turnhout: Brepols, 2018), 7-14.

${ }^{24}$ See David D. Boyer, "The Role of Landscape in the Occupational History of Gerasa and its Hinterland," in Lichtenberger and Raja, Archaeology and History, 59-86; Also David Boyer, "An Analysis of the Historical Water Management System to Gerasa in the period $100 \mathrm{BC}$ to AD 700" (PhD diss. University of western Australia, 2019), 50-1.

${ }^{25}$ Boyer, "Analysis", 68-80.

${ }^{26}$ Kennedy, Identity, 55; Kennedy, Gerasa, 69-70; Achim Lichtenberger and Rubina Raja, "Water management in the North-West Quarter of Gerasa/Jerash," in Gerasa/Jerash: From the Urban Periphery, eds. Achim Lichtenberger and Rubina Raja (Aarhus: Fællestrykkeriet AU, 2017) 121-9; Achim Lichtenberger and Rubina Raja, "Living with and on the river-side. The example of Roman Antioch-on-the-Chrysorrhoas-formerly-called-Gerasa," in Water of Life : Essays from a symposium held on the occasion of Peder Mortensen's 80th birthday, eds. John Kuhlmann Madsen, Niels Overgaard Andersen and Ingolf Thuesen (Copenhagen: Forlaget Orbis, 2016), 98-115; Achim Lichtenberger, "Antioch at the Chrysorrhoas - Gerasa, but which river?," Syria 96 (2019): 471-6.

${ }^{27}$ Jacques Seigne, "De la grotte au périptère. Le sanctuaire de Zeus à Jerash," Topoi. Orient-Occident 7, no. 2 (1997): 993-1004; Getzel M. Cohen, The Hellenistic Settlements in Syria, the Red Sea Basin, and North Africa (Berkeley: University of California Press, 2006), 248-53; Nathanael J. Andrade, Syrian Identity in the Greco-Roman World (Cambridge: Cambridge University Press, 2013), 162; Achim Lichtenberger and Rubina Raja, "New archaeological research in the Northwest quarter of Jerash and its implications for the urban development of Roman Gerasa," American Journal of Archaeology 119, no. 4 (2015): 483-500.

${ }^{28}$ Carl Hermann Kraeling, Gerasa: city of the Decapolis: an account embodying the record of a joint excavation conducted by Yale University and the British School of Archaeology in Jerusalem (1928-1930), and Yale University and the American Schools of Oriental Research (1930-1931, 1933-1934) (New Haven Conn: American Schools of Oriental Research, 1938), 27-30; Achim Lichtenberger, "Artemis and Zeus Olympios in Roman Gerasa and Seleucid religious policy", in The Variety of Local Religious Life in the Near East in the Hellenistic and Roman Periods, ed. Ted Kaizer (Leiden and Boston: Brill, 2008), 133-53; Rubina Raja, R. Urban Development and Regional Identity in the Eastern Roman Provinces, 50 BC - AD 250: Aphrodisias, Ephesos, Athens, Gerasa (Copenhagen: Museum Tusculanum Press, 2012); Rubina Raja, "Changing spaces and shifting attitudes: Revisiting the Sanctuary of Zeus in Gerasa," in Cities and Gods: Religious Space in Transition, eds. T. Kaizer, A. Leone, E. Thomas and R. Witcher (Leuven: Peeters, 2013), 31-46.

${ }^{29}$ Cohen, Hellenistic Settlements.

${ }^{30}$ See now the critical assessment by Pierre-Louis Gatier, “Antioche du Chrysorhoas," Topoi 22, no. 1 (2018): 225-49.
} 
Jerash came under Roman rule with Pompey's conquest of Syria in 63 BCE, which also became the starting point of its civic era. ${ }^{31}$ The impressive architectural record that remains visible today to a large degree stems from the second and third centuries CE (Figure 3). ${ }^{32}$ Urban development in the Late Roman and Early Islamic period is also visible, through numerous churches, a large late antique synagogue and two early mosques. ${ }^{33}$ The Byzantine and Umayyad periods stand forth as a prosperous time for the city, despite evidence that the city was hit hard by the Justinianic Plague, which is seen through the discovery in the (by then abandoned) hippodrome of 2 mass graves of the mid-seventh century CE containing an estimated 230 plague victims, ${ }^{34}$ and, counter to earlier assessments, the transition from Roman to Arab rule seems not to have disturbed the urban life to any significant degree, ${ }^{35}$ although, as we shall see, this image is complicated by data from the riverine hinterland of the city. The earthquake that struck the region in the morning of January 18 $749 \mathrm{CE},{ }^{36}$ however, had devastating consequences for Jerash. Only a small urban nucleus survived in the short run, and this was also abandoned over time. ${ }^{37}$ Left to occasional squatters and the seasonal presence of nomadic pastoralists for an extended period of time, a limited resettlement took place in the middle Islamic period. ${ }^{38}$ The site was again all but given up and remained desolate until the arrival of Circassian settlers in 1878, which marked the start of modern urban development. ${ }^{39}$ The Circassian and Arab populations have since been joined by considerable contingents of Palestinian refugees, and present-day Jerash is a rapid-growing, medium-sized city, relying on tourism and challenged with balancing urban growth with heritage management and pressure on land and water resources. ${ }^{40}$

\footnotetext{
${ }^{31}$ Lichtenberger, Kulte und Kultur, 192; Cohen, Hellenistic, 249. Rubina Raja, Urban Development and Regional Identity in the Eastern Roman Provinces, 50 BC - AD 250: Aphrodisias, Ephesos, Athens, Gerasa (Copenhagen: Museum Tusculanum Press, 2012), 149.

${ }^{32}$ Kraeling, Gerasa, 11-25, 73-158; Seigne, 'De la grotte'; Andrade, Identity, 162-3; Lichtenberger and Raja, 'Archaeological Research', 482-5.

${ }^{33}$ Kraeling, Gerasa, 265-294; John Winter Crowfoot, “The churches of Gerasa, 1928, 1929," Palestine Exploration Quarterly 62, no. 1 (1930): 32-42; Estēe Dvorjetski, "The Synagogue-Church at Gerasa in Jordan. A Contribution to the Study of Ancient Synagogues," Zeitschrift des Deutschen Palästina-Vereins 121, no. 2 (2005): 140-67; Alan George Walmsley, Early Islamic Syria: An Archaeological Assessment (London: Duckworth, 2007), 83-7; Achim Lichtenberger and Rubina Raja, "From Synagogue to Church. The Appropriation of the Synagogue of Gerasa/Jerash under Justinian," Jahrbuch für Antike und Christentum 61 (2018): 85-100.

${ }^{34}$ Ina Kehrberg and Antoni A. Ostrasz, "Ancient Burials at the Hippodrome of Gerasa/Jarash," Annual of the Department of Antiquities of Jordan 58 (2017): 131-218; Michael McCormick, “Tracking Mass Death During the fall of Rome's Empire (I)," Journal of Roman Archaeology 28 (2015): 325-57.

${ }^{35}$ Michal Gawlikowski, “Jerash in early Islamic times," Oriente Moderno 84, no. 2 (2004): 469-76.

Lichtenberger and Raja, 'Archaeological research', 489; Walmsley, Early Islamic, 83-7; Achim Lichtenberger and Rubina Raja, "Defining Borders: The Umayyad-Abbasid Transition and the Earthquake of AD 749 in Jerash," in Byzantine and Umayyad Jerash reconsidered. Transitions, Transformations, Continuities, eds. Achim Lichtenberger and Rubina Raja (Turnhout: Brepols, 2019), 265-86.

${ }^{36}$ Shmuel Marco, Moshe Hartal, Nissim Hazan, Lilach Lev, and Mordechai Stein, “Archaeology, History, and Geology of the A.D. 749 Earthquake, Dead Sea Transform," Geology 31, no. 8 (2003): 665-8.

${ }^{37}$ Achim Lichtenberger, Rubina Raja, Christoph Eger, Georg Kalaitzoglou, and Annette Højen Sørensen, "A Newly Excavated Private House in Jerash. Reconsidering Aspects of Continuity and Change in Material Culture from Late Antiquity to the Early Islamic Period," Antiquité Tardive 24 (2016): 317-59; Louise Blanke, "Abbasid Jerash Reconsidered: Suburban Life in Jerash's Southwest District over the Longue Durée," in The Archaeology and History of Jerash: 110 Years of Excavations, eds. Achim Lichtenberger and Rubina Raja (Turnhout: Brepols, 2018), 39-57; Achim Lichtenberger and Rubina Raja, eds. Middle Islamic Jerash (9th Century-15th Century). Archaeology and History of an Ayyubid-Mamluk Settlement (Brepols: Turnhout, 2018).

${ }^{38}$ Lichtenberger and Raja, Middle Islamic Jerash.

${ }^{39}$ Kraeling, Gerasa, ix.

${ }^{40}$ Achim Lichtenberger and Rubina Raja, Late Hellenistic and Roman Antioch on the Chrysorhoas, also called Gerasa. A reappreciation of the evidence in the light of the findings of the Danish-German Jerash Northwest Quarter Project (2011-2017), in Hellenistic and Roman Gerasa. The archaeology and history of a Decapolis city, eds. Achim Lichtenberger and Rubina Raja (Brepols: Turnhout, 2020), 7-54.
} 


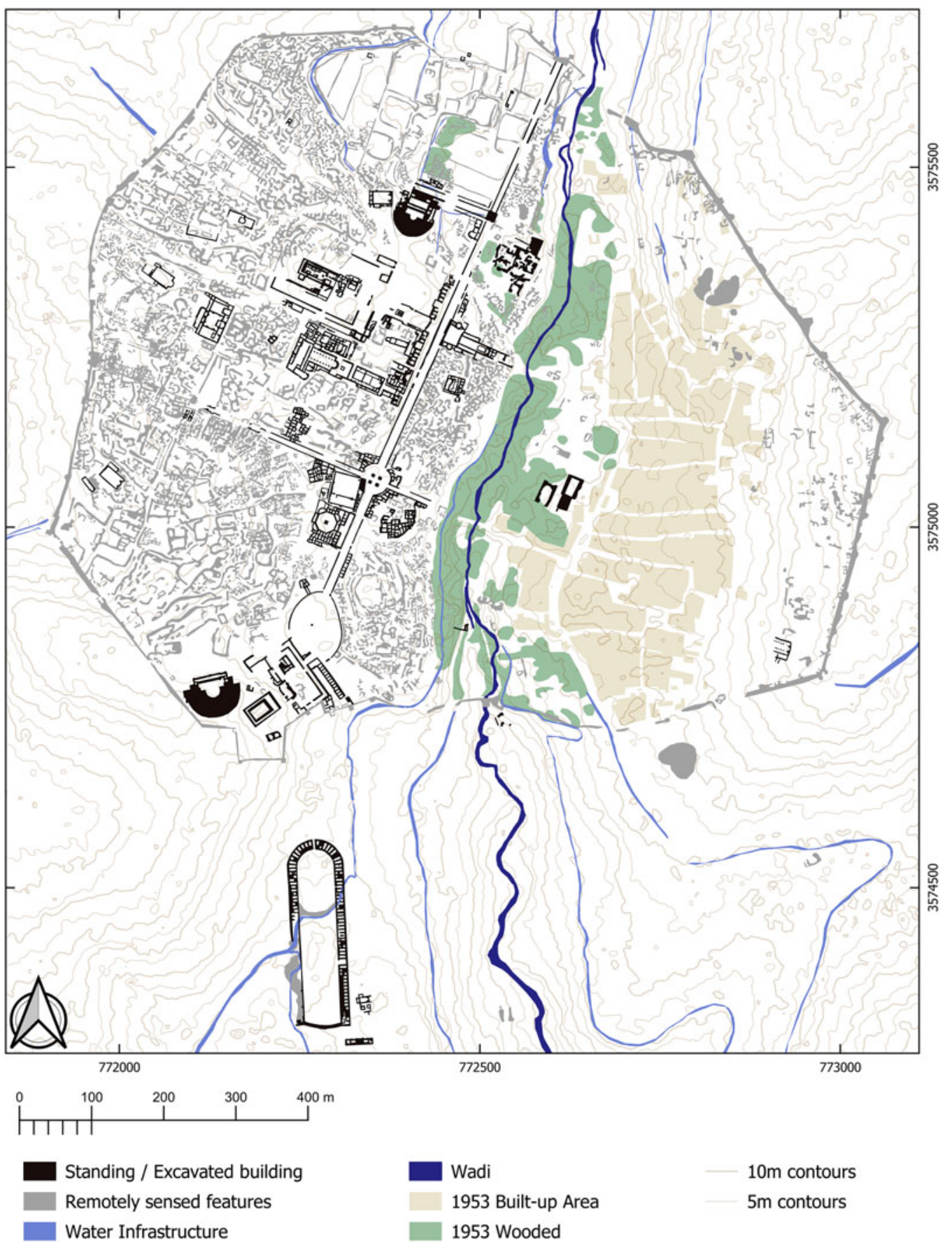

Figure 3. Map of Gerasa (Achim Lichtenberger, Rubina Raja and David Stott, "Mapping Gerasa: a new and open data map of the site," Antiquity 93.367 (2019): e7 DOI: https://doi.org/10.15184/aqy.2019.9). 


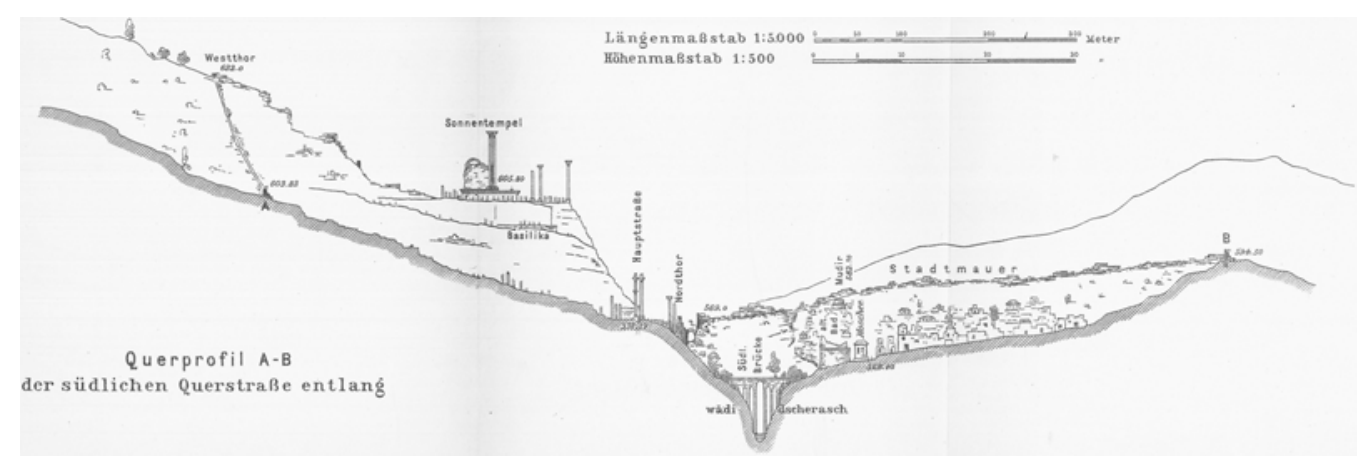

Figure 4. East-West section through the city of Gerasa (Gottlieb Schumacher, "Dscherash," Zeitschrift des Deutschen Palästina-Vereins 25 (1902): 109-77).

\section{The river in the city}

Gerasa was encircled by city walls and the city had a main thoroughfare, a colonnaded street running from north to south about 1.2 kilometres long. It is bisected by two other colonnaded streets running east-west. ${ }^{41}$ The city itself is divided into an eastern and a western part by the steep wadi (riverbed) (Figure 4). Crossing between the east and west parts of Jerash was in antiquity provided by several bridges. ${ }^{42}$ The wadi and the bridges had a profound impact on the urban movement. After the bridges fell out of use, the connections between the east and the west side of the city were interrupted and it is not by chance that when modern resettlement was begun, it did not extend across the wadi, but was restricted to the east side of the site. Since the Kerawan spring and the wadi lay on lower ground than the western part of the city, water supply to most parts of the city that were on higher altitude had to be provided by a complex system of aqueducts, cisterns and pipes leading the water from the upstream area of Suf into the city and its adjacent fields. ${ }^{43}$ Furthermore, without active management, the steepness of the wadi resulted in substantial erosion and water-related soil movement, both persistent over extended periods of time and by more extreme events such as landslides.

How is the history of a site like Jerash connected with changing variables such as climate, subsistence, geopolitics, disease and natural disaster? Answers might be sought at a range of interconnected scales, all of which, however, may be reflected in the natural archive of the sediments left by the river that gave life and for a while name to the city.

\section{Microregional context: the Jerash-Wadi Suf watershed}

Understanding the microregional context of Jerash, defined here as the Jerash-Wadi Suf watershed through time, requires careful integration of the natural sciences, archaeological survey and historical sources. Enabled by the aeolian (windborne) deposition of quartz containing Saharan dust throughout the Pleistocene, ${ }^{44}$ optically stimulated luminescence (OSL) profiling and dating of sedimentary sequences trace patterns of sediment movement within the wadi that reflect phases of

\footnotetext{
${ }^{41}$ M. Tabaczek, Zwischen Stoa und Suq. Die Säulenstraßen im Vorderen Orient in römischer Zeit unter besonderer Berücksichtigung von Palmyra (PhD dissertation Cologne, 2002), 161-86; Ross Burns, Origins of the Colonnaded Streets in the Cities of the Roman East (Oxford: Oxford University Press, 2017).

${ }^{42}$ Lichtenberger and Raja, 'Living with and on'.

${ }^{43}$ Boyer, "Analysis", 81-93.

${ }^{44}$ Arie S. Issar and Hendrik J. Bruins, 'Special Climatological Conditions in the Deserts of Sinai and the Negev during the Latest Pleistocene', Paleogeography, Palaeoclimatology, Palaeoecology 43, no. 1-2 (1983): 63-72; Arie S. Issar et al., "A Paleoclimatic Model to Explain Depositional Environments during Late Pleistocene in the Negev," in In Progress in Desert Research, eds. Louis Berkofsky and Morton G. Wurtele (Totowa: Rowman \& Littlefield, 1987), 302-9; Bernhard
} 
stable landscape, accumulation of waterborne (fluvial) sediments and movement of (colluvial) sediments down slopes. ${ }^{45}$ These science-based observations give interpretations of the upper wadi (above Jerash city; Profile 2, Figure 1) as an intact landscape with little or no sediment movement and a freely flowing river until $640 \pm 240 \mathrm{CE}$. This suggests a balanced and continuous management of the fluvial landscape that regulated floods and preserved soil. Subsequent to this, waterborne sedimentation and wadi infilling through to $760 \pm 40 \mathrm{CE}$ suggest the beginnings of land degradation with declining maintenance of agricultural infrastructures. From $760 \pm 40 \mathrm{CE}$, slope movement sediment deposition indicates a further acceleration of land degradation and a severely compromised agricultural infrastructure on the wadi slopes. Analyses of the middle wadi catchment (below/south of Jerash city; Profile 3, Figure 1 indicate that waterborne sediment accumulation continued, but that slopes remained intact until $1400 \pm 60 \mathrm{CE}$. Slope wash sediment deposition points towards accelerating land degradation after this point of time. Further down in the lower wadi catchment (Profile LW1, Figure 1), waterborne sediment accumulation commenced from $510 \pm 310 \mathrm{BCE}$, paralleling dates from soils underlying Jerash, until $760 \pm 40 \mathrm{CE}$ when, as in the upper wadi, slope wash sediments and accelerating degradation becomes evident.

Notwithstanding the beginnings of limited waterborne sediment accumulation in the lower wadi that indicates initial catchment disturbance associated with the onset of urbanization in the second century $\mathrm{BC}$, the sediment sequences testify to a stable and intact catchment with no indication of over-exploitation until $640 \pm 240 \mathrm{CE}$. Although much work remains to be undertaken on the landscape archaeology and history of this microregion, the evidence points to careful landscape management of both soil and water resources in the upper wadi. A Roman-period inscription associates the upper wadi area with the 'gardeners of the upper valley', ${ }^{46}$ and, although yet to be dated, the extensive agricultural terraces enhancing crop rooting depth and water holding capacity may have their origins in this period, ${ }^{47}$ maintaining and provisioning the Roman-period oil presses found in and around Jerash. ${ }^{48}$ Similarly, water management infrastructures were developed during this era, including the introduction of water gates regulating water reaching the city, the creation of the Birketein cistern complex and soils-based evidence of micro sediments associated with irrigation practice in the vicinity of the early city. ${ }^{49}$ These archaeological indicators point to a strong and centralized urban-hinterland governance and robust social and economic networks within a fluctuating climate, but with increasing precipitation. This was an internally contained microregion, networked economically with its meso- and macro regions in variable but untroubling environmental conditions regulated by careful management.

The onset of waterborne sediment accumulation beginning to infill the upper wadi within the wide time bracket of $640 \pm 240 \mathrm{CE}$ indicates local soil erosion from previously stable agricultural

Lucke et al., "Red Mediterranean Soils in Jordan: New Insights in their Origin, Genesis, and Role as Environmental Archives," Catena 112 (2014): 4-24.

${ }^{45}$ Achim Lichtenberger et al., "Urban-Riverine Hinterland Synergies in Semi-Arid Environments: Millennial- Scale Change, Adaptations, and Environmental Responses at Gerasa/Jerash,” Journal of Field Archaeology 44, no. 4 (2019): 333-51.

${ }^{46}$ Pierre-Louis Gatier, "Nouvelles inscriptions de Gérasa," Syria 62 (1985): 297-312; Lichtenberger and Raja, 'Living with'; Jacques Seigne, "Remarques préliminaires à une étude sur l'eau dans la Gerasa antique," in Men of Dikes and Canals: The Archaeology of Water in the Middle East. International symposium held at Petra, Wadi Musa (H.K. of Jordan) 15-20 June, 1999, eds. Hans-Dieter Bienert and Jutta Häser (Rahden: M. Leidorf, 2004), 173-85.

${ }^{47}$ Brian Beckers and Brigitta Schütt, "The Chronology of Ancient Agricultural Terraces in the Environs of Petra," in Men on the Rocks: The Formation of Nabataean Petra, eds. Michel Mouton and Stephan. G. Schmidt (Berlin: Logos, 2013), 313-22; Gershon Edelstein and Mordechai E. Kislev, "Mevasseret Yerushalayim: The Ancient Settlement and its Agricultural Terraces," The Biblical Archaeologist 44, no 1 (2015): 53-6; Zvi Ron, 'Agricultural Terraces in the Judean Mountains', Israel Exploration Journal 16 (1966): 33-49, 111-22.

${ }^{48}$ Georg Kalaitzoglou, Achim Lichtenberger, and Rubina Raja, "Preliminary Report of the Second Season of the DanishGerman Jarash Northwest Quarter Project 2012," Annual of the Department of Antiquities of Jordan 57 (2013): 57-79.

${ }^{49}$ Lichtenberger et al., 'Urban-riverine'; Lichtenberger and Raja, 'Living with'; Ian Simpson, Achim Lichtenberger and Rubina Raja, unpublished data. Also see Achim Lichtenberger and Rubina Raja, Management of water resources over time in semi-arid regions: The case of Gerasa/Jerash in Jordan, WIREs Water 2019; e1403, 1-19; Boyer, "Analysis". 
land surfaces, with land management, organization and regulation less effective in responding to a series of interrelated meso- and macroregional stresses. These include significant and well documented dry periods in the paleo-climatic record c. 536-800 CE affecting socio-economic shocks and coinciding with a decline in long-distance trade across the eastern Mediterranean, ${ }^{50}$ the impact of the recurring Justinianic Plague pandemic that commenced 540-541 CE and which had a real immediacy for Jerash as evidenced in the mid-seventh-century mass graves uncovered in the hippodrome, and a 540-640 CE century of regional Sassanian and Roman conflict followed by Arab invasion. ${ }^{51}$ The 'perfect storm' of these existential events was a tipping point for this microregion with the Wadi River at no point after c. $640 \mathrm{CE}$ being the free-flowing Chrysorrhoas of antiquity, ${ }^{52}$ and whose impacts may yet be seen, with further research, in the agricultural landscape infrastructure of the wadi and in the archaeology of households. These events also served to reduce physical and social resilience in the microregion to future environmental and social stresses. Evidence from other microregions indicates that post-tipping point scenarios include the prospect of a greater likelihood of new and more frequent major changes in the complex relationships between societies and their environments. ${ }^{53}$

Slope wash deposits superimposed on the waterborne deposits and commencing from $760 \pm 40$ $\mathrm{CE}$ are best explained as a result of the $749 \mathrm{CE}$ earthquake superimposed on an agricultural system and city, already in decline. Factors contributing to a decline in land management again included difficult dry climatic conditions, the Umayyad-Abbasid conflict 747-750 CE and possibly the regional plague outbreak of $744 \mathrm{CE}$; these circumstances would have further accentuated the failure of the remaining agricultural terraces and associated irrigation systems. ${ }^{54}$ After the earthquake, the city was largely abandoned not simply because of the earthquake, but because of the vulnerabilities inherited from earlier societal and environmental changes together with mesoand macroregional mediated impacts. Slope wash deposits are also evident in the middle wadi below the city, but only commencing post $1400 \pm 60 \mathrm{CE}$, prior to which waterborne sediments continued to accumulate. This continuation implies contrasting microregional responses with land management here was sufficiently careful for slopes to remain intact until $1400 \pm 60 \mathrm{CE}$. This opens the possibility that while agriculture was largely abandoned on upper and lower wadi locations post the $749 \mathrm{CE}$ earthquake, agriculture had contracted to the middle wadi just below the remaining city. These slope failure indicators from $1400 \pm 60 \mathrm{CE}$ may be tentatively related to Ayyubid-Mamluk city abandonment after the eleventh/twelfth-century CE resettlement of

\footnotetext{
${ }^{50}$ Ulf Büntgen et al., "Cooling and societal change during the Late Antique Little Ice Age from 536 to around 660 AD," Nature Geoscience 9, no. 3 (2016): 231-6; Yehouda Enzel et al., "Late Holocene Climates of the Near East Deduced from Dead Sea Level Variations and Modern Regional Winter Rainfall," Quaternary Research 60, no. 3 (2003): 263-73; Martin Finné et al., "Climate in the Eastern Mediterranean, and adjacent Regions, during the Past 6000 Years - A Review," Journal of Archaeological Science 38, no. 12 (2011): 3153-73; Kyle Harper and Michael McCormick, "Reconstructing Roman Climate," in The Science of Roman History: Biology, Climate, and the Future of the Past, ed. Walter Scheidel (Princeton: Princeton University Press, 2018), 11-52; Arie S. Issar and Mattanyah Zohar, Climate Change : Environment and History of the near East (Berlin: Springer, 2007); Ian Orland et al., "Climate Deterioration in the Eastern Mediterranean as revealed by Ion Microprobe Analysis of a Speleothem that Grew from 2.2 to 0.9 ka in Soreq Cave, Israel," Quaternary Research 71, no. 1 (2009): 27-35; Newfield, 'The Climate Downturn'; John Haldon, Byzantium in the Seventh Century: The Transformation of a Culture (Cambridge: Cambridge University Press, 1990).

${ }^{51}$ Mischa Meier, "The 'Justinianic Plague': The Economic Consequences of the Pandemic in the Eastern Roman Empire and its Cultural and Religious Effects,” Early Medieval Europe 24 (2016): 267-92; Kehrberg and Ostrasz, 'Ancient Burials'.

${ }^{52}$ John Haldon, The Empire That Would Not Die: The Paradox of Eastern Roman Survival 640-740 (Harvard: Harvard University Press, 2016). Alan Walmsley, "Economic Developments and the Nature of Settlement in the Towns and Countryside of Syria-Palestine, ca. 565-800," Dumbarton Oaks Papers 61 (2007): 319-52.

${ }^{53}$ Keir Magalie Strickland et al., "Hydraulic complexities: Collapse and resilience in Sri Lanka," in Water and Society: From Ancient Times To The Present, eds. Federica Sulas and Innocent Pikirayi (Routledge: London, 2018), 259-81; Margaret C. Nelson, "Climate challenges, vulnerabilities and food security," Proceedings of the National Academy of Sciences 113 (2016): 298-303.

${ }^{54}$ Lichtenberger et al., 'Urban-Riverine'.
} 
Jerash, which saw investment in water management infrastructure during a period of favourable climatic conditions and expanding long-distance trade. ${ }^{55}$

The water system of Jerash and its hinterland entailed extensive infrastructure and careful management that can be traced from well before the first evidence of urban settlement until the modern period. ${ }^{56}$ The evidence of observed spatial and temporal sedimentary sequences in the microregion add to this, representing outcomes of attempts to control the environment, or lack of such, in the form of complex wadi watershed responses to meso- and macroregional environmental and social changes, mediated by local management activities, and so challenge the wider archaeological and paleo-environmental record for an explanation. In doing so, nuanced narratives of urban-hinterland relationships and their nesting within wider spatial and temporal scales become possible. On the Jerash-Wadi Suf scale, microregional evidence highlights the significance of proactive governance and management of meso- and macroregional drivers of change to ensure the viability of urban and hinterland cultural landscapes. In contrast, inherited vulnerabilities together with new meso- and macroregional social and environmental impacts are reflected in the failure of management and loss of landscape integrity.

\section{Mesoregional context: the semi-arid Near East}

While urban settlement at Jerash has a start, a series of peaks, lows, unknowns and even hiatuses, the ecological microregion was never abandoned. Fewer details are known due to the scarcity and nature of evidence, but the semi-arid Near East, including the highlands of Ajlun, has been home to sheep- and goat herding pastoralist groups since the late Neolithic, ${ }^{57}$ and to camel nomads since the early first millennium BCE. ${ }^{58}$ Fluctuations in land use between settled agriculture and pastureland has traditionally been explained by two mechanisms. Nomads seem to have encroached on agricultural land in periods of either dry climate and/or weak government. The theoretical lower annual precipitation limit for the cultivation of barley (Hordeum vulgare) is $200 \mathrm{~mm}$. Farmers operating near this limit, however, will experience harvest failure in the regularly occurring dry years. This will have to be compensated by a working market economy or other redistributive systems that supplies food to the farming population in such cases. Investment in hydraulic infrastructure as that evidenced in the urban core and hinterland of Jerash (bridges, water gates, terraces, cisterns, aqueducts, etc.) requires a certain security and stability. In dry periods, the historical limit of settled agriculture has generally moved towards the $400 \mathrm{~mm}$ isohyet, where stable harvests may be expected even in dry years. ${ }^{59}$

For the region of Jerash, the closest paleo-climatological series results from studies of changes in the sea level of the Dead Sea and from speleothems from the Soreq caves west of Jerusalem. Both have relevance to Jerash beyond the geographical proximity (c. 80 kilometres). Water flows into the Dead Sea from the north, including from Wadi Jerash, by way of the Jordan River, and the sea level is thus in part a product of rainfall in the region. ${ }^{60}$ The records from the Soreq caves reflect

\footnotetext{
${ }^{55}$ Lichtenberger and Raja, 'Middle-Islamic'; Lichtenberger et al., 'Urban-Riverine'.

${ }^{56}$ Boyer, "Analysis".

${ }^{57}$ Kay Prag, “Ancient and Modern Pastoral Migration in the Levant," Levant 17 (1985): 81-8; Mohammad B. Tarawneh and Fawzi Q. Abudanah, "Subsistence of early pastoral nomadism in the southern Levant: new data from eastern Bayir," Syria. Archéologie, art et histoire 90 (2013): 231-52; Oystein Sakala LaBianca, Lorita E. Hubbard and Leona Glidden Running, Sedentarization and Nomadization: Food System Cycles at Hesban and Vicinity in Transjordan (Berrien Springs: Andrews University Press, 1990).

${ }^{58}$ Jan Retsö, "The Domestication of the Camel and the Establishment of the Frankincense Road from South Arabia," Orientalia Suecana 40 (1991): 187-219; Steven A. Rosen and Benjamin A. Saidel, "The Camel and the Tent: An Exploration of Technological Change among Early Pastoralists,” Journal of Near Eastern Studies 69, no. 1 (2010): 63-77.

${ }^{59}$ Norman N. Lewis, Nomads and Settlers in Syria and Jordan, 1800-1980 (Cambridge: Cambridge University Press, 1987); Arie S. Issar and Mattanyah Zohar, Climate Change: Environment and History of the near East (Berlin: Springer, 2007).

${ }^{60}$ Revital Bookman et al., "Quaternary Lake Levels in the Dead Sea Basin: Two Centuries of Research," Geological Society of America Special Paper 401 (2006): 155-70.
} 
cyclone activity in the Mediterranean that feeds winter rains near Jerash as well as near Jerusalem. While the series and their interpretations differ, the general picture is that of comparably wet conditions from the initial phases of urban development at Jerash and throughout the phase of intensive building activity until ca $200 \mathrm{CE} .{ }^{61}$ This coincides with what is known as the Roman Warm Period/Roman Climate Optimum. Reviews of regional paleo-climatological studies in the Levant show a similar pattern of fluctuations between dry and wet periods, but are not in agreement on chronology. ${ }^{62}$ This might have to do with the significant margins involved in dating different series. ${ }^{63}$ After $200 \mathrm{CE}$, most studies suggest generally drier, but also more variable climate. One recent assessment combining environmental with a variety of archaeological proxies and historical data suggest that this culminated in a so-called megadrought ca 350-470 CE, followed by two centuries of historically wet conditions ca $470-670 \mathrm{CE}{ }^{64}$ This period of generally favourable climate, however, was interrupted by a spell of abrupt cooling and dry conditions following the volcanic $536 \mathrm{CE}$ climate event. ${ }^{65}$ There is general agreement that conditions in the Levant became drier than they had been during the Roman Warm- and Byzantine periods from the late seventh century until the ninth century and that conditions became more benign after that. ${ }^{66}$ Xoplaki et al. have compared paleo-climatological proxies and modelled precipitation and temperature with the (also modelled) 1651-1850 average. They identify subperiods within the Crusader, Mamluk and Ottoman periods with increased environmental stress, the two former being of special relevance to Jerash.

As pointed out by Xoplaki et al. for the second millennium CE and as demonstrated by the different timelines in reconstructions of climatic fluctuations in the mid-first millennium, local climates within the mesoregion might have behaved differently, and the dating of various proxies remains too inaccurate to draw conclusions about correlation and much less causation between changing climate and short-term societal developments. ${ }^{67}$ Some more general observations may, however, be made with regard to Jerash and climate change on the mesoregional level based on the archaeological record from the city and the soil record from the riverine hinterland. The start and first peak of urban development take place during the relatively wet conditions of the Roman Warm Period. Urban life continues through the late Roman mega-drought of the late fourth and fifth centuries. While urban building activity decreases after c. 200-250 CE and turns towards churches from the fourth century $\mathrm{CE}$, this is an empire-wide trend in the Roman world, and drier climate is not directly reflected in the urban archaeological record, and also cannot at the present be traced in the riverine sediments, indicating a degree of urban resilience and the upkeep of agricultural and hydrological infrastructure. There is evidence for negative effects on the urban

\footnotetext{
${ }^{61}$ Yehouda Enzel, Amotz Agnon and Mordechai Stein, "Late Holocene Lake Levels of the Dead Sea," Geological Society of America Bulletin 116, no. 5-6 (2004): 555-71; Ian J. Orland et al., "Climate Deterioration in the Eastern Mediterranean as Revealed by Ion Microprobe Analysis of a Speleothem that Grew from 2.2 to $0.9 \mathrm{ka}$ in Soreq Cave, Israel," Quaternary Research 71, no. 1 (2009): 27-35; Kyle Harper and Michael McCormick, "Reconstructing Roman Climate," in The Science of Roman History: Biology, Climate, and the Future of the Past, ed. Walter Scheidel, (Princeton: Princeton University Press, 2018), 11-52.

${ }^{62}$ Harper and McCormick, 'Reconstructing'; Adam Izdebski et al., "The Environmental, Archaeological and Historical Evidence for Regional Climatic Changes and their Societal Impacts in the Eastern Mediterranean in Late Antiquity," Quaternary Science Reviews 136 (2016): 189-208; Inga Labuhn et al., "Climatic Changes and their Impacts in the Mediterranean during the first millennium AD," Late Antique Archaeology 12, no. 1 (2016): 65-88.

${ }^{63}$ Izdebski et al., 'The Environmental Evidence', 196.

${ }^{64}$ Izdebski et al., 'The Environmental Evidence', 196.

${ }^{65}$ Izdebski et al., 'The Environmental Evidence', 197; Timothy P. Newfield, 'The Climate Downturn'; Matthew Toohey et al., "Climatic and Societal Impacts of a Volcanic Double Event at the Dawn of the Middle Ages," Climatic Change 136, no. 3-4 (2016): 401-12.

${ }^{66}$ Orland et al., 'Climate'; Harper and McCormick, 'Climate change'; Izdebski et al, 'The Environmental evidence', 196; Issar and Zohar, Climate Change, 217-19; Labuhn et al., 'Climatic Changes'; Xoplaki et al., 'Modelling Climate'.

${ }^{67}$ Xoplaki et al. 'Modelling Climate'; Labuhn et al. 'Changes'; Izdebski et al, 'The Environmental evidence', Harper and McCormick, 'Reconstructing'.
} 
population during the Justinianic Plague ${ }^{68}$ which onset coincides with the abrupt 536 CE climate event and prolonged wars with the Sasanian Empire. This period also sees the commencement of increased waterborne sediment in the river valley, indicating land degradation upstream of Jerash. While urban life in Jerash did continue and thrived into the Byzantine and early Islamic periods as reflected in the construction of churches and mosques, this raises the question of whether the geopolitical situation (plague, war, Sasanian occupation, Islamic conquest, abrupt climate crisis) is reflected in stress on the until then carefully maintained city-hinterland balance. After a millennium of urban life and unlike after earlier earthquakes, Jerash was not rebuilt after the earthquake in $749 \mathrm{CE}$, which coincided with a period of gradually drier climate and land abandonment all over the Near East, ${ }^{69}$ one of the last recorded outbreaks of the Justinianic Plague (744 CE), as well as the shift of the imperial capital from nearby Damascus to Mesopotamian Harran (744 CE), and the war that lead to the downfall of the Umayyad dynasty (747-750 CE). The discontinuation of the urban settlement was reflected in the hinterland, as indicated by the increase of slope wash sediments visible in the wadi profiles signifying the abandonment of terracing and other investments in water and soil management. The next urban settlement at the site coincides with wet climate and large-scale investment in hydraulic infrastructure during the Middle Islamic (Ayyubid-Mamluk) period. This suggests that urban life at Jerash and the microregion of the Ajlun highlands was indeed sensitive to long-term climate changes, but that such changes could be mitigated through investment in hydrological infrastructure, and that such changes on the scale experienced in the arid Near East in the so-called Long Classical Millennium (LCM) ${ }^{70}$ from the Hellenistic through the Umayyad periods, cannot alone explain the ups and downs of Jerash's urban biography.

\section{Macroregional scale: Syrian-Arabian Deserts, Mediterranean}

Early twentieth-century traveller and archaeologist Gertrude Bell famously described the semiarid Near East as 'Between the Desert and the Sown'. ${ }^{71}$ In ecological terms, this corresponds to what is known as an ecotone, in this case between the Mediterranean and the Syrian and Arabian Deserts. An ecotone is a zone of transition and interaction between two biomes. The term is used both at the macroscale, as is the case here, and for more localized settings such as hillslopes and river estuaries. ${ }^{72}$ Ecotones, with traits from both (or all) the biomes they border on, have generally been studied for their potential biodiversity, but while this is often the case ecotones are also marginal in the true sense of the word. ${ }^{73}$ While approaches that see the Near East as a contact zone rather than a periphery have been dominant in historical scholarship for some time, this has generally taken the political unit of the Roman Empire as the point of departure. ${ }^{74}$

\footnotetext{
${ }^{68}$ Kehrberg and Ostrasz, 'Ancient Burials'. On the broader effects cf. Meier, 'Justinianic Plague'. See, however, also the recent critical assessment by Lee Mordechai et al., “The Justinianic Plague: An Inconsequential Pandemic?," Proceedings of the National Academy of Sciences 116, no. 51 (2019): 25546-25554; Lee Mordechai and Merle Eisenberg, "Rejecting Catastrophe: The Case of the Justinianic Plague," Past \& Present 244, no. 1 (2019): 3-50.

${ }^{69}$ Izdebski et al., 'The Environmental evidence'.

${ }^{70}$ Kennedy, Gerasa, 15.

${ }^{71}$ Gertrude Lowthian Bell, The Desert and the Sown, (London: W. Heinemann, 1907).

${ }^{72}$ Carole L. Crumley, “Analyzing Historic Ecotonal Shifts,” Ecological Applications 3, no. 3 (1993): 377-84; Salit Kark, "Ecotones and Ecological Gradients," in Ecological Systems: Selected Entries from the Encyclopedia of Sustainability Science and Technology, ed. Rik Leemans (New York: Springer, 2013), 147-60.

${ }^{73}$ Kark and Salit, "Ecotones"; Robert E. Rhoades, "Archaeological Use and Abuse of Ecological Concepts and Studies: The Ecotone Example," American Antiquity 43, no. 4 (1978): 608-14.

${ }^{74}$ For example, Fergus Millar, The Roman Near East $31 B C$ and AD337 (Cambridge: Harvard University Press, 1994); Maurice Sartre, The Middle East under Rome (Cambridge: Harvard University Press, 2005); Michael Sommer, Roms orientalische Steppengrenze: Palmyra, Edessa, Dura-Europos, Hatra: Eine Kulturgeschichte von Pompeius bis Diocletian (Stuttgart: Franz Steiner, 2005).
} 
For situating Jerash in the wider networks of interaction in the Old World, the ecotone concept is useful, as sociopolitical systems to a considerable degree coincided with ecological zones.

Janet Abu-Lughod approached world trade on the eve of the fourteenth-century plague pandemic in terms of eight overlapping circuits, together spanning the distance from the East China Sea to the Atlantic Ocean. ${ }^{75}$ While these circuits to some extent were shaped by the formation and disintegration of large empires, they were largely defined by regional climate regimes and continental outlines that required change in the mode of transport, for instance between sea and overland or riverine networks. In the transition zones, ecotones in a wide sense of the word, we find the main entrepôts of pre-modern world trade. Centres came and went with fluctuating political fortunes, but such focal points remained within the same mesoregions, as the cases of Alexandria/ Cairo, Palmyra/Aleppo and Ctesiphon/Baghdad arguably show. ${ }^{76}$ Ecological zones also shaped the geopolitical environment of Jerash for long periods. The Roman and Byzantine empires to a large extent coincided with the Mediterranean biotope, and most of the Syrian and Arabian Deserts largely remained outside effective imperial control except perhaps in the Rashidun and Umayyad periods.

That cities like Jerash, situated in what arguably amounted not only to ecological, but also to imperial ecotones, faced opportunities, as well as challenges due to their geographical location, is not an argument of environmental determinism, but rather the opposite. Early observers did indeed include Jerash amongst a number of so-called caravan cities in the arid Near East, believed to have based their prosperity on long-distance trade. ${ }^{77}$ Later, commentators have pointed out that the evidence for active involvement in such activities remains limited to the Nabateans and Palmyra, ${ }^{78}$ and that the success of these places was a result not only of location, but also of agency. ${ }^{79}$ Jerash was not situated on the major Roman-period north-south nor east-west routes, albeit well connected by secondary roads. ${ }^{80}$ Arguably much of Jerash's interest as a case study, along with remarkable preservation, lies exactly in its unremarkable history and archaeology, making it 'a very fair specimen of a second-rate provincial Roman town' as an unimpressed nineteenth-century visitor put it. ${ }^{81}$ This outwardly unremarkable history nevertheless involves historical events and dynamics directly shaped by Jerash's situation between the Mediterranean and the Arabian macroregions. Amongst them are the Hellenistic origins of the urban settlement, its likely occupation by the Nabatean kingdom, ${ }^{82}$ the conquest by Roman (63 BCE), Palmyrene (270 CE), Sasanian (614 CE) and Arab (636 CE) armies, the turmoils of the Jewish War (66-70 CE), ${ }^{83}$ and the patronage and investment offered by Roman, Umayyad

\footnotetext{
${ }^{75}$ Janet L. Abu-Lughod, Before European Hegemony: The World System A.D. 1250-1350 (New York: Oxford University Press, 1989).

${ }^{76}$ Eivind Heldaas Seland, “Als Indien das Römische Reich entdeckte: Exploration und Handel im Indischen Ozean vom Osten aus gesehen," in Maritime Entdeckung und Expansion. Kontinuitäten, Parallelen und Brüche von der Antike bis in die Neuzeit, ed. Raimund Schultz (Oldenbourg: De Gruyter, 2019), 109-20.

${ }^{77}$ Mikhail I. Rostovtzeff, Caravan Cities (Oxford: Clarendon Press, 1932); Klaus Stefan Freyberger, Die frühkaiserzeitlichen Heiligtümer der Karawanenstationen im hellenisierten Osten (Mainz: von Zabern, 1998).

${ }^{78}$ Fergus Millar, “Caravan Cities: The Roman near East and Long Distance Trade by Land," in Modus Operandi: Essays in Honor of Geoffrey Rickman, eds. Michel Austin, Jill Harries and Christopher Smith (London: Institute of Classical Studies, School of Advanced Study, University of London, 1998): 119-37.

${ }^{79}$ Gary K. Young, Rome's Eastern Trade: International Commerce and Imperial Policy, 31 Bc-Ad 305 (London: Routledge, 2001); Eivind Heldaas Seland, Ships of the Desert, Ships of the Sea: Palmyra in the World Trade of the First Three Centuries CE (Wiesbaden: Harrasowitz, 2016).

${ }^{80}$ David Kennedy, The Roman Army in Jordan (London: Council for British Research in the Levant, 2004), 110; Richard J.A Talbert ed. Barrington Atlas of the Greek and Roman World (Princeton, NJ: Princeton University Press, 2000 ), 69.

${ }^{81}$ Alexander C. Lindsay, Letters on Egypt, Edom, and the Holy Land, II (London: Henry Colburn, 1838), 107.

${ }^{82}$ Kraeling, Gerasa, 36-9.

${ }^{83}$ Achim Lichtenberger, “The First Jewish Revolt as Reflected on the City Coins of the Southern Levant," Israel Numismatic Research 13 (2018): 121-38.
} 
and much later Mamluk authorities, ${ }^{84}$ as well as the city's integration into Christian networks in Late Antiquity, ${ }^{85}$ and later into the Islamic world. The outcomes of these encounters between imperial agencies and local responses are represented in the archaeological, architectural and epigraphic records of Jerash, ${ }^{86}$ and might reflect back on our understanding of macroregional development. In the case of Jerash, the 749 CE historical watershed also needs to be viewed on the background of the dynastic politics of the early Islamic caliphates. The last Umayyad caliph in $744 \mathrm{CE}$ moved the capital away from Damascus, and from $750 \mathrm{CE}$ and the new Abbasid dynasty set up their base in Mesopotamia. ${ }^{87}$ This resulted in a neglect of the Bilad al-Sham region, including the area where Jerash was situated. However, a conundrum to be considered is still whether or which cause and effect we are seeing: was the move of the capital the cause of the neglect of Bilad al-Sham, or was the decline of the area, in turn, the reason for the transfer of the capital? Was Jerash's society not sufficiently resilient rebuild the city, its infrastructure and manage the hinterland after the earthquake because of lack of imperial investment or had Jerash and the region become too unimportant as a result of environmental changes leading to decline and the transfer of the capital of the Early Islamic caliphate? It was likely a combination of both, a conclusion that underlines the obvious need for political and environmental history to be interlinked on local and global scales.

Traditional histories of the Near East take states and empires as their protagonists, so also most of the brief list of events and polities above, which treats Jerash as a periphery mainly to the Mediterranean, but at times also to the Persian and Arabian worlds, points of view that have obvious relevance with regard to the urban period of the site. ${ }^{88}$ As implied by the adoption of the ecotone as a tentative unit of analysis, however, Jerash and its hinterland were also peripheral to a different macroregion, namely the nomadic worlds of the Arabian and Syrian Deserts. ${ }^{89}$ These regions, although generally considered separately in geographic literature, were united by a predominantly nomadic lifestyle, with camel pastoralism and pockets of oasis agriculture in the heartlands, surrounded by sheep and goat pastoralism in the outer zone, along with cities, villages, states and agriculture on the rim. Arguably Nabatean, Arab and also Umayyad footprints in the history of Jerash relate to this world of the desert as well as to that of states and empires. More difficult to trace is the agency of 'People without history', ${ }^{90}$ in this case, the people who maintained their nomadic lifestyle in their encounter with Jerash and other cities of the semi-arid Near East. In the long periods after the urban centre at Jerash was all but abandoned in the mideighth century, until it was re-established under Ayyubid/Mamluk control, and then from the fifteenth century until the settlement of modern Jerash by Circassian migrants, Jerash, the water resources in the hinterland and the microregion of the Ajlun highlands were primarily utilized by nomadic pastoralists as a periphery to the Syrian and Arabian Deserts. This said, although travellers of the nineteenth century to Jerash emphasize the desertedness and dangers of the site, they still provide clues that Jerash was not an empty site and several families lived there already before

\footnotetext{
${ }^{84}$ Kraeling, Gerasa, 44-56; Walmsley, Early Islamic, 83-7.

${ }^{85}$ Kraeling, Gerasa, 171-3.

${ }^{86}$ Kennedy, 'Identity'.

${ }^{87}$ Early capitals of Islamic culture. The artistic legacy of Umayyad Damascus and Abbasid Baghdad (650-950) (Munich: Hirmer, 2014).

${ }^{88}$ Øystein Sakala LaBianca, “Thinking Globally and Also Locally: Anthropology, History and Archaeology in the Study of Jordan's Past," in Crossing Jordan: North American Contributions to the Archaeology of Jordan, eds. Thomas Evan Levy, P. M. Michèle Daviau, and Randall W. Younker (Sheffield: Equinox, 2007): 3-11.

${ }^{89}$ William Lancaster and Fidelity Lancaster, People, Land and Water in the Arab Middle East: Environments and Landscapes in the Bilâd Ash-Shâm (Amsterdam: Harwood Academic, 1999); Kurt Franz, "The Bedouin in History or Bedouin History," Nomadic Peoples 15, no. 1 (2011): 11-53.

${ }^{90}$ Eric R. Wolf Europe and the People without History (Berkeley: University of California Press, 1982); Nicole Boivin and Michael D. Frachetti., Globalization in Prehistory: Understanding Contact and Exchange between Peoples without History (Cambridge: Cambridge University Press, 2018).
} 
the Circassian resettlement. ${ }^{91}$ The survival of the Semitic toponym of Gerasa from pre-Hellenistic until modern times is arguably one indication of rural and non-sedentary populations also constituting an element of continuity in the long-term history of the region.

The urban centre of Jerash is situated only a few kilometres from the eastern watershed of Wadi Jerash. Several boundary markers have been located, ${ }^{92}$ and Kennedy suggests that the city territory on the eastern side coincided with this watershed (Figure 1). As he points out this situates Jerash as an agricultural town, which, unlike cities such as Palmyra and Homs, did not incorporate parts of the semi-desert/steppe into their territories, in line with the observation by others, that Jerash was never a caravan city as such..$^{93}$ Land east of the watershed, where agriculture is today assisted by drilled wells, used to be pastureland until relatively recent times and was likely largely so also in antiquity. ${ }^{94}$

We know little about the people who used this territory in the heyday of Jerash. Some 100 kilometres to the northeast, however, in the desert east of Jabal Hawran, nomadic populations left c. 35,000 texts inscribed in Safaitic script on basalt rocks. Smaller numbers of texts are also known from other places, some as far afield as Syrian Palmyra, Saudi Arabia and Lebanon with a curious outlier in Italian Pompeii. The few dated and dateable events mentioned in these texts all place them in the late Hellenistic until the late Roman period. ${ }^{95}$ While the basalt desert where the bulk of inscriptions have been found must have been a region of core interest to these groups, they were highly mobile, and it is likely that they also utilized nearby sections of desert frontier, where they lacked their preferred medium (basalt) to leave inscriptions in the same astonishing number. At least three Safaitic inscriptions have direct relevance to Jerash. One is a funerary monument from the village of al-Ayn al Jurn, 14 kilometres NW of Jerash. ${ }^{96}$ The second text from Wadi Salma on the Syrian-Jordanian border, was left by an individual en route from Gilead, corresponding to the modern region of Balqa, c. 25 kilometres SW of Jerash, to Tadmor (Palmyra) in Syria, 360 kilometres NE, who must have passed through the territory of Jerash on his way. ${ }^{97}$ The third inscription, from an unspecified site in the al-Mafraq region directly east of Jerash, seems to stem from a military expedition heading towards that city. ${ }^{98}$ Even when allowing for the limitations imposed by the small number, lack of context, fixed dates and difficulties of interpretation connected with these texts, they highlight how the ecotone between deserts and agricultural land in which Jerash was situated offered possibilities as well as liabilities for urban and nomadic populations alike. For nomads, cities and their hinterlands were attractive trading partners and pasturelands as well as potential targets for raids. Nomads could be taxed, e.g. for access to pastures by urban and settled populations and they could be traded with, but they also

\footnotetext{
${ }^{91}$ Achim Lichtenberger and Rubina Raja, By the Gold River: Gerasa through the Eyes of the 19th and 20th Century Visitors (Turnhout: Brepols, in preparation).

${ }^{92} J a c q u e s$, Seigne, “Les Limites Orientale Et Méridionale Du Territoire De Gerasa”, Syria 74 (1997): 121-40; Jacques Seigne, "Nouvelles inscriptions rupestres de Gerasa et de son territoire," Syria 96 (2019): 371-85.

${ }^{93}$ Kennedy, Identity, 58-54; Millar, 'Caravan cities'.

${ }^{94}$ Kennedy, "Identity", 52. Martha Mundy, "Qada Cajlun in the Late Nineteenth Century: Interpreting a Region from the Ottoman Land Registers," Levant 28, no. 1 (1996): 77-95.

${ }^{95}$ Online Corpus of the Inscriptions of Ancient North Arabia: http://krc.orient.ox.ac.uk/ociana/index.php (accessed FEB 21 2020); Macdonald, Michael CA. "Nomads and the Hawrān in the Late Hellenistic and Roman Periods: A Reassessment of the Epigraphic Evidence”, Syria (1993): 303-413.

${ }^{96}$ Hani Hayajneh, "An Ancient North Arabian Inscribed Nefesh Stele from the Vicinity of Jerash (Nortwestern Jordan)," Syria 94 (2017): 253-60.

${ }^{97} \mathrm{KRS}$ 15/KR 1, OCIANA, Online Corpus of the Inscriptions of Ancient North Arabia, http://krc.orient.ox.ac.uk/ociana/ corpus/pages/OCIANA_0020643.html (accessed FEB 21 2020); Geraldine King, "The Basalt Desert Rescue Survey and some Preliminary Remarks on the Safaitic Inscriptions and Rock Drawings," Proceedings of the Seminar for Arabian Studies 20 (1990): 55-78.

${ }^{98} \mathrm{WH}$ 1859, OCIANA, Online Corpus of the Inscriptions of Ancient North Arabia, http://krc.orient.ox.ac.uk/ociana/ corpus/pages/OCIANA_0012712.html (accessed FEB 21 2020). Cf. also the evidence for deities related to caravans and nomads Lichtenberger, Kulte und Kultur, 313.
} 
represented a potential threat in the shape of the well-attested raids against travellers and settlements, which was partly the reason for the heavy military presence along the desert edge. ${ }^{99}$ Nomadic pastoralists were active in the region of Jerash before, during and after the periods of urban settlement. Climate change affected nomads as well as settled populations. Periods of moist climate historically offered richer pastures in the desert and enabled increased herd sizes, ${ }^{100}$ and dry periods, like the Late Antique/Early Medieval Little Ice Age in the sixth to ninth centuries, and the Little Ice Age of the sixteenth to eighteenth centuries coincide with nomadic encroachment on agricultural lands and the movement and replacement of nomadic groups. ${ }^{101}$

\section{Conclusion: Jerash and global history}

Global-scale events and developments, both in the metaphorical 'world-system' or 'Lebenswelt' senses, as well in the literal 'planet-wide' meaning, influenced what happened in Jerash. The city was founded as a result of the policies and rivalries of faraway kings of Macedonian descent. Script, architecture and material life reveal how imperial templates, mainly of Mediterranean origin, but common to different extents from the Iberian Peninsula to Central Asia, and from Germany to the Red Sea, were adopted and adapted. Settlement history, as well as sediment records from the riverine hinterland of the city, reflect system-scale events such as the Justinianic Plague and the rise, crises and collapse of the Roman authority in the region, but also the local and regional effects of truly global developments such as the Roman Climate Optimum and the Late Antique/Early Medieval Ice Age/Climate Pessimum and the early modern Little Ice Age. Glimpses of dynamics between nomads and settled populations are visible in archaeological records of land use, settlement patterns and in the scarce historical sources. Whether these should be read primarily through lenses of macroregional and global climate history or in the long anthropological tradition of nomad-settled interaction is amongst the questions where our data is lacking, but that future work on Jerash might shed light on.

Our case for doing detailed case studies in the context of global history, however, goes both ways. While global perspectives are necessary for understanding regional, local and even individual developments, these also feed back to, nuance and challenge macroscale narratives by creating points of reference and comparison. On microregional scale, changes in the urban environment and landscape water management evidenced in archaeological and scientific data demonstrate how a local community was able for a long time, but then at a certain point no more, to build resilience through sustainable management of and adaptation to water resources in a marginal region. The history was repeated, on a smaller scale and with a shorter duration, during the Middle Islamic period. Both cases at the same time highlight the importance of climate change in long-term history and the possibilities for people to adjust to changing conditions in ways that in turn changed the environment in lasting and profound manners. The grim evidence of the mass graves in the hippodrome shows how a fresh outbreak could devastate a small urban settlement even a century after the first wave of the Justinianic Plague, now known to have been a proto global event, ${ }^{102}$ challenging recent studies minimizing the impact of exactly that

\footnotetext{
${ }^{99}$ S. Thomas Parker, "Projecting Power on the Periphery: Rome's Arabian Frontier East of the Dead Sea," In Levy et al., Thinking Globally, 349-57.

John H.W.G. Liebeschuetz, “Arab Tribesmen and Desert Frontiers in Late Antiquity,” Journal of Late Antiquity 8, no. 1 (2015): 62-96; Macdonald, 'Nomads'.

${ }^{100}$ Eugen Wirth, “Das Problem der Nomaden Im heutigen Orient,", Geographische Rundschau 21 (1969): 41-51.

${ }^{101}$ Werner Caskel, Die Bedeutung Der Beduinen in der Geschichte der Araber (Cologne -Opladen: Westdeutscher Verlag, 1953); Kurt Franz, "The Bedouin in History or Bedouin History?," Nomadic Peoples 15, no. 1 (2011): 11-53.

${ }^{102}$ George D. Sussman, "cientists Doing History: Central Africa and the Origins of the First Plague Pandemic," Journal of World History 26, no. 2 (2016): 325-54; Monica H. Green, “The Globalisations of disease," in Human Dispersal and Species Movement: From Prehistory to the Present, eds. Nicole Boivin, Rémy Crassard, and Michael D. Petraglia (Cambridge: Cambridge University Press, 2017): 494-520.
} 
pandemic. ${ }^{103}$ The mesoregional level offers insights into the plasticity of human-environment relations, where nomadic pastoralism and settled agriculture experienced periods of intensification and abatement, ${ }^{104}$ which in part coincide with fluctuations in the imperial presence and territorial control. On macroregional level, the case of Jerash and its hinterland show local responses to fluctuating political power relations, economic ties and religious networks as well as to regional and global-scale climate change. These processes play out on scales suitable for global history narratives even if not global in a physical sense, such as that of the Mediterranean, the Old World or the Levant, ${ }^{105}$ and in the case of Jerash with its situation on ecological and metaphorical (e.g. imperial, religious, cultural) ecotones, even serve to integrate such narratives on a larger geographical scale. For approximately seven centuries following the second-century BCE foundation, the urban-hinterland relations of Jerash as evidenced in the city's ability to maintain its agricultural and hydrological resources, remain balanced in the face of war, earthquakes, climate change, religious change and epidemics. While such changes, stresses and shocks are well reflected in the archaeological records of the urban environment, the settlement overall remained resilient in adapting to new conditions. Strains on resource management becomes evident in the last centuries of the urban history, but it is the disastrous $749 \mathrm{CE}$ earthquake that changes the trajectory of the microregion from urban/agricultural to nomadic/pastoral. Arguably, the cumulative long-term effects of war, epidemics, religious strife and deteriorating climate are visible in the failure to maintain the agricultural and hydrological balance and are the underlying causes behind the decision to abandon a settlement which at the time had been successful for almost a millennium.

As we step out of the history of Jerash, we return to the challenge to historians to integrate material and scientific data in historical narratives. The case of Jerash, an average, and in most respects unremarkable place that hardly figures in the historical record, shows that, despite this, such data do add to and drive value to the discussion of historical questions. This does not underplay human historical experience or agency, but frames people as agents also with regard to their environment, thus contributing to our understanding of processes leading up to the challenges posed by the emerging Anthropocene period and so-called 'Great acceleration' of recent centuries and decades. ${ }^{106}$ Combining archaeological data on the urban environment, scientific studies of land management and climate change with the more generalized historical record of the region does enable us to write the history of the city and the region in some detail. The detailed case of Jerash also has value as a case study on micro-, meso- and macroregional and global history levels. Climate change, empires, epidemics, nomads and wars all played the roles in shaping the history of Jerash, but none of them can explain the major shifts in the long-term history of the city and the region by themselves. This is a lesson against monocausal and deterministic interpretations of historical development, which is transferable to other case studies built on less detailed or less cross-disciplinary evidence. In our view, this also highlights the potential and continued relevance of historical scholarship in a time where our data on the distant past is increasingly produced by the natural sciences. Jerash's long-standing ability to and ultimately failure to cope with change can only be appreciated when different strands of evidence are combined and treated as products of culturally as well as environmentally situated and mediated practices in the past.

\footnotetext{
${ }^{103}$ Mordechai et al., 'Justinianic Plague'; Mordechai and Eisenberg, 'Rejecting Catastrophe'.

${ }^{104}$ LaBianca, Hubbard and Running, Sedentarization; Øystein Sakala LaBianca and Bethany Walker, 'Tall Hisban: Palimpsest of Great and Little Traditions of Transjordan and the Ancient Near East', in Levy et al., Crossing Jordan.

${ }^{105}$ Eivind Heldaas Seland, "The Indian Ocean and the Globalisation of the Ancient World," Ancient West and East 7 (2008): 67-79; David Abulafia, "Mediterranean History as Global History," History and Theory 50, no. 2 (2011): 220-8; Stordalen and LaBianca, Levantine Entanglements.

${ }^{106}$ John R. McNeill and Peter Engelke, The Great Acceleration: An Environmental History of the Anthropocene Since 1945 (Harvard: Harvard University Press, 2016); Will Steffen et al., "The Trajectory of the Anthropocene: The Great Acceleration," The Anthropocene Review 2 no, 1 (2015): 81-98.
} 
Achim Lichtenberger is Professor of Classical Archaeology and director of the Archaeological Museum at the Münster University. Together with Rubina Raja, he is co-director of the Danish-German Jerash Northwest Quarter Project. Other current fieldwork projects are located in Armenia and Israel.

Rubina Raja is Professor of Classical Archaeology and Director of the Centre for Urban Network Evolutions. She directs the Danish-German Jerash Northwest Quarter Project together with Achim Lichtenberger. She also directs fieldwork projects in Pompeii and Rome together with Danish and Italian colleagues and heads the corpus project Palmyra Portrait Project.

Eivind Heldaas Seland is Professor of Ancient History and Pre-Modern Global History, Department of Archaeology, History, Cultural Studies and Religion, University of Bergen. His interests are in how economy, environment, ideology and politics interacted in ancient societies and how historians and archaeologists cast climate as an agent of historical change.

Ian A. Simpson is Professor of Geography and Environmental Sciences at the University of Stirling, Scotland, UK. He has published extensively on the geoarchaeology, heritage and environmental history of the North Atlantic region and of South Asia.

Cite this article: Lichtenberger A., Raja R., Seland EH., and Simpson IA. 2021. Scaling up and zooming in: global history and high-definition archaeology perspectives on the longue durée of urban-environmental relations in Gerasa (Jerash, Jordan). Journal of Global History 16: 395-414, doi:10.1017/S1740022821000012 